\title{
APLIKASI SISTEM PENYIDIKAN BERBASIS CLIENT SERVER PADA DITRESKRIMSUS POLDA RIAU
}

\author{
Sunarti ${ }^{1}$, Ira Fitriandini2) \\ STIKOM Pelita Indonesia \\ ${ }^{1}$ sunarti@lecturer.pelitaindonesia.ac.id, 2irafitri.andini@yahoo.co.id
}

\begin{abstract}
Ditreskimsus Riau Police is implementing elements of the basic tasks under the police chief of Riau that handle specific types of crimes that are divided into four (4) subfields crime. Community service activities in terms of criminal investigation to preparing reports conducted semi computerization and disposition reporting process is still done manually into separate problems that need to be designed a client server-based system that can be accessed by the management and personnel directly. This study aims to generate client server-based investigation system that can help Ditreskrimsus Riau Police Office in providing better services, quickly and systematically. The research methodology used is the System Development Life Cycle (SDLC). SDLC is the methodology used to develop, maintain, and replace information systems. Through research and development of information systems in the Riau Police Ditreskrimsus result that the utilization of the application of investigation information systems can provide a solution in the investigation process.
\end{abstract}

Key words : Ditreskrimsus Riau Police, Special crimes, investigation, Client server, $S D L C$

Abstrak. Ditreskimsus Polda Riau merupakan unsur pelaksana tugas pokok yang berada dibawah Kapolda Riau yang menangani jenis tindak kejahatan khusus yang terbagi dalam 4 (empat) subbidang kejahatan. Aktivitas pelayanan masyarakat dalam hal penyidikan tindak pidana hingga pembuatan laporan dilakukan secara semi komputerisasi dan proses disposisi laporan yang masih dilakukan secara manual menjadi permasalah tersendiri sehingga perlu dirancang sebuah sistem berbasis client server yang dapat diakses oleh pimpinan dan personil secara langsung. Penelitian ini bertujuan untuk menghasilkan sistem penyidikan berbasis client server yang dapat membantu Kantor Ditreskrimsus Polda Riau dalam memberikan pelayanan yang lebih baik, cepat dan sistematis. Metodologi penelitian yang digunakan adalah System Development Life Cycle (SDLC). SDLC merupakan metodologi yang digunakan untuk mengembangkan, memelihara, dan mengganti sistem informasi. Melalui penelitian dan pengembangan sistem informasi pada Ditreskrimsus Polda Riau diperoleh hasil bahwa pemanfaatan penerapan sistem informasi penyidikan ini dapat memberikan solusi dalam proses penyidikan.

Kata Kunci : Ditreskrimsus Polda Riau, kejahatan khusus, Penyidikan, Client server, SDLC.

\section{PENDAHULUAN}

Kepolisian di Negara modern yang demokratis mempunyai fungsi pelayanan keamanan kepada individu, komunitas (masyarakat setempat) dan negara. Pelayanan keamanan ini bertujuan untuk menjaga, mengurangi rasa takut dari ancaman dan gangguan serta menjamin keamanan dilingkungannya secara berkesinambungan untuk meningkatkan kualitas hidup dan produktivitas masyarakat. Dalam memberikan pelayanan, Polisi mempunyai kewenangan untuk menegakkan hukum 
dan keadilan serta memerangi kejahatan yang mengganggu dan merugikan warga masyarakat dan negara.

Dalam wilayah provinsi, Kepolisian Daerah (Polda) merupakan pelaksana tugas dan wewenang Polri yang berada dibawah Kapolri. Dalam melaksanakan tugas, Polda menyelenggarakan beberapa fungsi, salah satunya yaitu pemberian pelayanan kepolisian kepada masyarakat dalam bentuk penerimaan dan penanganan laporan polisi atau pengaduan untuk selanjutnya melakukan penyidikan tindak pidana sesuai dengan ketentuan peraturan perundang-undangan. Berdasakan Peraturan Kapolri (Perkap) No 22 Tahun 2010 tentang Susunan organisasi dan tata kerja pada tingkat Kepolisian Daerah, Direktorat Reserse Kriminal di pisahkan berdasarkan jenis tindak kejahatan yang di tangani menjadi 2 (dua) bagian yaitu, Direktorat Reserse Kriminal Umum (Ditreskrimum) dan Direktorat Reserse Kriminal Khusus (Ditreskrimsus).

Ditreskimsus merupakan unsur pelaksana tugas pokok pada tingkat Polda yang menangani tindak kejahatan khusus. Subdit I Tipid Indagsi adalah salah satu bagian/sub dari Ditreskrimsus yang bertugas melakukan penyidikan tindak pidana industri perdagangan dan asuransi yang terjadi di daerah hukum Polda. Subdit II Tipid perbankan, money laundering dan cyber crime, fiskal moneter dan devisa (fismondev) adalah salah satu bagian/sub dari Ditreskrimsus yang bertugas melakukan penyidikan tindak pidana perbankan, pencucian uang dan kejahatan maya yang terjadi di daerah hukum Polda. Subdit III Tipidkor adalah salah satu bagian/sub dari Ditreskrimsus yang bertugas melakukan penyidikan tindak pidana korupsi yang terjadi di daerah Polda Riau. Subdit IV Tipidter adalah salah satu bagian/sub dari Ditreskrimsus yang bertugas melakukan penyidikan Tindak pidana Tertentu.

Polda Riau beserta jajaran melalui Humas Polda Riau, telah menyiapkan fasilitas untuk membantu masyarakat yang datang secara langsung untuk mengakses informasi sesuai ketentuan dalam UU No. 14/2008 atau informasi lain bersifat real time, peristiwa penting maupun penjelasan dari pejabat Polri-Polda Riau serta menyediakan fasilitas interaktif dalam rangka akurasi informasi yang dapat dipertanggungjawabkan (akuntabel). Namun berbagai keterbatasan selalu menjadi kendala, antara lain menyangkut sumber daya dan fasilitas itu sendiri.

Dalam menerima dan menangani pengaduan tindak kejahatan, masalah yang sering terjadi pada Ditreskrimsus Polda Riau yaitu belum tersedianya tata kelola berkas penyidikan secara terkomputerisasi sehingga tidak adanya database yang menyimpan data penyidikan laporan polisi. Dari hasil penelitian yang dilakukan, semua surat menyurat yang berkaitan dengan penyidikan masih diagendakan dan disimpan secara manual. Apabila surat yang berkaitan dengan penyidikan tersebut sewaktu-waktu dibutuhkan maka akan menghabiskan waktu yang lama untuk mencarinya. Hal ini berdampak pada kualitas pelayanan yang diberikan kepada masyarakat yang akan semakin menurun.

Disisi lain, proses disposisi yang selama ini dilakukan masih secara manual yaitu ditulis tangan pada selembar kertas kecil yang sangat beresiko terjadinya kehilangan. Melalui disposisi pimpinan dapat mendelegasikan kewenangannya serta pengambilan keputusan untuk tindakan 
selanjutnya terhadap setiap laporan dan surat yang diterima. Jadi disposisi menjadi hal yang rahasia dan harus dijaga kamanannya, hal ini juga belum tersolusi dengan baik. Maka untuk memenuhi layanan dari pihak - pihak tertentu secara proporsional dan sistematis diperlukan sebuah teknologi berbasis jaringan client-server yang dapat diakses oleh pimpinan dan personil untuk dapat mengatasi permasalah tersebut.

Tingginya tingkat kejahatan

khusus di wilayah Provinsi Riau juga menjadi alasan bagi Kepolisian untuk meningkatkan keamanan diseluruh wilayah Polda Riau dan jajarannya. Pembagian wilayah kejahatan akan membantu pimpinan dalam menempatkan personil sehingga dapat menurunkan tingginya tingkat kejahatan pada wilayah-wilayah tertentu. Hal ini tentu akan sangat membantu mengingat selama ini tidak ada sebuah sistem khusus yang dapat membagi wilayah kejahatan khusus di Provinsi Riau. Untuk itu sistem yang dirancang ini juga dilengkapi dengan kemampuan untuk membagi wilayah berdasarkan jenis kejahatannya.

\section{TINJAUAN PUSTAKA}

\section{Konsep Dasar Sistem}

Menurut I Putu Agus Eka Pratama (2014), Sistem didefinisikan sebagai sekumpulan prosedur yang saling terhubung untuk melakukan suatu tugas bersama-sama. Sebuah sistem terdiri atas 3 (tiga) komponen utama yaitu software, hardware dan brainware. Software mencakup semua perangkat lunak yang dibangun dengan bahasa pemrograman tertentu, untuk kemudian menjadi sistem operasi, aplikasi dan driver yang saling bekerjasama agar komputer berjalan dengan baik. Hardware mencakup semua perangkat keras seperti motherboard, processor, VGA dan lain-lain. Brainware mencakup kemampuan otak manusia berupa ide, pemikiran, dan analisis dalam menciptakan dan menggabungkan hardware dan software. Penggabungan software dan hardware dengan bantuan brainware yang melalui sejumlah prosedur akan menciptakan sebuah sistem yang bermanfaan bagi pengguna.

\section{Pengertian Informasi}

Informasi mempunyai manfaat dan peranan yang sangat dominan dalam suatu organisasi/perusahaan. Tanpa adanya suatu informasi dalam suatu organisasi, maka pimpinan tidak dapat mengambil keputusan dengan cepat dan mencapai tujuan dengan efektif dan efisien.

\section{Ditreskrimsus}

Ditreskimsus merupakan unsur pelaksana tugas pokok yang berada dibawah Kapolda. Ditreskrimsus berdiri sejak tahun 2010 sesuai dengan Peraturan Kapolri (Perkap) nomor 22 tahun 2010 tentang susunan organisasi dan tata kerja pada tingkat kepolisian daerah. Ditreskrimsus bertugas menyelenggarakan penyelidikan dan penyidikan tindak pidana khusus dan koordinasi, serta pengawasan operasional. Adapun tindak pidana khusus yang dimaksud yaitu :

1. Tindak pidana menyangkut kejahatan Industri, perdagangan dan asuransi (Indagsi), antara lain :
a. Perfileman, Budaya Tanaman, Telekomunikasi dan Penyiaran
b. Perumahan, Pemukiman dan Investasi
c. Industri, Pangan dan Perlindungan Konsumen
d. Perdagangan dan Karantina 
2. Tindak pidana menyangkut kejahatan Fiskal, moneter dan devisa (Fismondev), antara lain :
a. Perbankan
b. Uang dan dokumen palsu
c. Pencucian uang
d. Kejahatan dunia maya

3. Tindak pidana menyangkut kejahatan korupsi (Tipidkor), antara lain :

a. Dana Usaha Negara dan Dana Pemerintah

b. Dana Kredit Usaha

c. Dana Bantuan

d. Dana Pembangunan dan Proyek

4. Tindak pidana menyangkut kejahatan tertentu (Tipidter), antara lain :

a. Kehutanan dan Pertanian

b. Pertambangan

c. Lingkungan Hidup

d. Tenaga Kerja.

\section{Pengertian Penyidikan}

Penyidikan merupakan tahapan penyelesaian perkara pidana setelah penyelidikan yang merupakan tahapan permulaan mencari ada atau tidaknya tindak pidana dalam suatu peristiwa. Ketika diketahui ada tindak pidana terjadi, maka saat itulah penyidikan dapat dilakukan berdasarkan hasil penyelidikan. Pada tindakan penyelidikan, penekanannya diletakkan pada tindakan "mencari dan menemukan" suatu "peristiwa" yang dianggap atau diduga sebagai tindakan pidana. Sedangkan pada penyidikan titik berat penekanannya diletakkan pada tindakan "mencari serta mengumpulkan bukti". Penyidikan bertujuan membuat terang tindak pidana yang ditemukan dan juga menentukan pelakunya. Pengertian penyidikan tercantum dalam Pasal 1 butir 2 KUHAP yakni dalam Bab I mengenai Penjelasan Umum, yaitu: "Penyidikan adalah serangkaian tindakan penyidik dalam hal dan menurut cara yang diatur dalam undang-undang ini untuk mencari serta mengumpulkan bukti yang dengan bukti itu membuat terang tentang pidana yang terjadi dan guna menemukan tersangkanya".

Berdasarkan rumusan Pasal 1 butir 2 KUHAP, unsur-unsur yang terkandung dalam pengertian penyidikan adalah:

a. Penyidikan merupakan serangkaian tindakan yang mengandung tindakantindakan yang antara satu dengan yang lain saling berhubungan;

b. Penyidikan dilakukan oleh pejabat publik yang disebut penyidik;

c. Penyidikan dilakukan dengan berdasarkan peraturan perundangundangan;

d. Tujuan penyidikan ialah mencari dan mengumpulkan bukti, yang dengan bukti itu membuat terang tindak pidana yang terjadi, dan menemukan tersangkanya.

Berdasarkan keempat unsur tersebut dapat disimpulkan bahwa sebelum dilakukan penyidikan, telah diketahui adanya tindak pidana tetapi tindak pidana itu belum terang dan belum diketahui siapa yang melakukannya. Adanya tindak pidana yang belum terang itu diketahui dari penyelidikannya.

\section{Pengertian Penyidik}

Penyidik menurut Pasal 1 butir ke-1 KUHAP adalah pejabat polisi Negara Republik Indonesia atau pejabat pegawai negeri sipil tertentu yang diberi wewenang khusus oleh undang-undang untuk melakukan penyidikan. KUHAP lebih jauh lagi mengatur tentang penyidik dalam pasal 6, yang memberikan batasan pejabat penyidik dalam proses pidana. Adapun batasan pejabat dalam tahap penyidikan tersebut adalah pejabat penyidik POLRI dan Pejabat penyidik 
negeri sipil. Disamping yang diatur dalam Pasal 1 butir ke 1 KUHAP dan Pasal 6 KUHAP, terdapat lagi Pasal 10 yang mengatur tentang adanya penyidik pembantu disamping penyidik.

\section{Pemrograman Berorientasi Objek}

Pemrograman berorientasi objek adalah berusaha untuk membuat suatu software sebagai sekumpulan objek yang unik dimana objek ini terdiri dari atribut dan operasi yang merupakan satu kesatuan yang saling melengkapi. Semua data dan fungsi di dalam paradigma ini dibungkus dalam kelas-kelas atau objekobjek. Setiap objek dapat menerima pesan, memroses data, dan mengirim pesan ke objek lainnya.

\section{Client Server}

Pada dasarnya, terdapat tiga komponen client server, yaitu:

1. Client

Client merupakan terminal yang digunakan oleh pengguna untuk meminta layanan tertentu yang dibutuhkan. Terminal client dapat berupa PC, Ponsel, komunikator, robot, televisi dan peralatan lain yang membutuhkan informasi.

2. Middleware

Middleware merupakan

komponen perantara yang memungkinkan client dan server untuk saling terhubung dan berkomunikasi satu sama lain. Object Requeset Broker merupakan middleware yang memungkinkan objek client dan server untuk berinteraksi satu sama lain tanpa harus menyesuaikan perangkat keras atau system operasi kedua belah pihak. Middleware menerjemahkan hasil proses dari server agar dapat dipahami oleh client.

3. Server
Server merupakan pihak yang menyediakan layanan. Server ini dapat berupa basis data SQL, Transaction Monitor, server groupware, server objek atau web. Secara umum, server dapat berperan menerima pesan permintaan layanan dari client, memproses permintaan tersebut dan mengirimkan hasil permintaan kepada client.

\section{Jaringan}

Kecepatan perkembangan teknologi menjadikan proses transformasi informasi sebagai kebutuhan utama manusia yang akan semakin mudah didapattkan dengan cakupan yang semakin luas. Perbedaan dalam hal pengumpulan, transportasi, penyimpanan serta pemrosesan informasi akan semakin hilang, hingga akan tercipta sebuah sistem standar yang akan memudahkan manusia dalam mengembangkan teknologi sistem informasi (Edi S. Mulyanta, 2005).

Menurut Wiharsono (2007), jaringan komputer adalah kumpulan sejumlah peripheral yang terdiri dari beberapa komputer, printer, LAN Card, dan peralatan lain yang saling terintegrasi satu sama lain. Informasi dan data bergerak melalui kabel-kabel sehingga memungkinkan pengguna jaringan komputer dapat saling bertukar dokumen dan data, mencetak pada printer yang sama dan bersama sama menggunakan hardware/software yang terhubung dengan jaringan.

\section{METODE PENELITIAN}

Metodologi adalah kerangka teoritis yang digunakan peneliti untuk menganalisa, mengerjakan atau menghadapi masalah yang dihadapi. Sedangkan kerangka teoritis merupakan metode-metode ilmiah yang diterapkan 
dalam pelaksanaan tugas (Prof. Dr. Gorys Keraf, 2001).

Metodologi untuk pengembangan sistem merupakan proses standar yang digunakan tim pengembang untuk menghubungkan semua langkah yang diperlukan untuk menganalisa, merancang, mengimplementasi, dan memelihara sistem informasi. Adapun metodologi yang sampai saat ini masih sesuai untuk pedoman dalam pengembangan sistem adalah SDLC (System Development Life Cycle).

SDLC adalah metodologi yang digunakan untuk mengembangkan, memelihara, dan atau mengganti sistem informasi. Gambar berikut adalah bagan dari SDLC yang umum dimana terdiri atas tujuh fase. SDLC juga sering disebut metodologi 'Waterfall' karena lebih menyerupai ait terjun. Berikut gambar dari SDLC dengan tujuh fase :

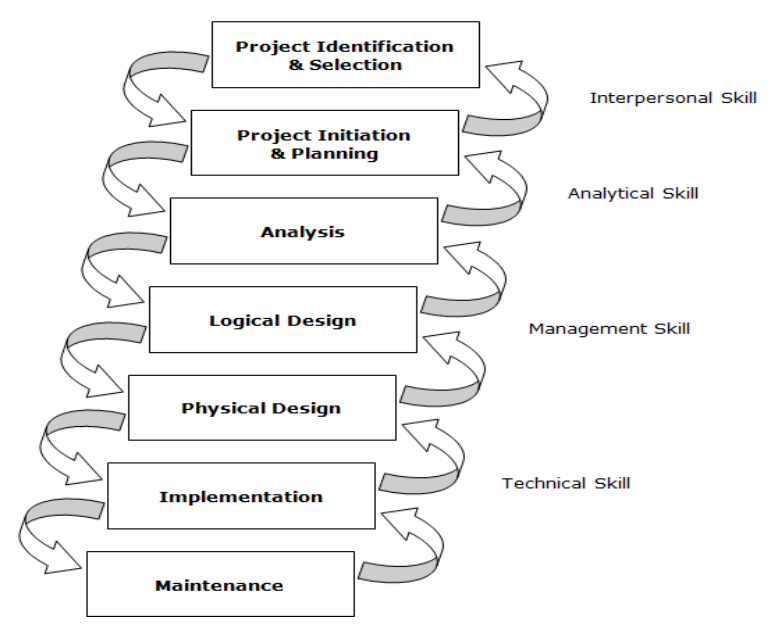

Gambar 3.2 Tahapan System Development Life Cycle

\section{Identifikasi dan Seleksi}

Langkah pertama yang dilakukan dalam penelitian adalah dengan memantau, menjabarkan dan menyimpulkan kegiatan Sistem Informasi (SI) yang ada di setiap bagian maupun di lingkungan Ditreskrimsus Polda Riau.
Hal ini dilakukan untuk mengidentifikasi kemungkinan perancangan terhadap kegiatan SI (khusus kegiatan penyidikan) yang terjadi saat ini. Adapun teknik yang digunakan untuk mendukung pelaksanaan langkah pertama SDLC ini adalah dengan pemantauan secara langsung ke lokasi terjadinya kegiatan SI, lalu mewawancarai staff penyidik, staff bagbinopsnal dan staff bagurkeu yang ada di Ditreskrimsus Polda Riau.

\section{Inisialisasi dan Perencanaan}

Setelah dilakukan identifikasi serta penyeleksian SI, langkah selanjutnya adalah inisialisasi serta perencanaan pembuatan sistem, dan ruang lingkup sistem yang akan dibangun. Pelaksanaan langkah kedua SDLC ini menghasilkan batasan ruang lingkup sistem yang akan dibangun meliputi pada pengolahan data penyidikan yang meliputi data laporan polisi dan biaya penyidikan.

\section{Analisa atau Penganalisaan}

Langkah ketiga dari SDLC ini merupakan langkah yang paling sulit karena harus menetapkan bentuk dasar dari struktur rancangan SI baru. Pada langkah ini terbagi menjadi tiga sub langkah yaitu :

\section{Requirement Determination}

Pada sub langkah ini adalah melanjutkan langkah satu sebelumnya secara lebih terperinci.

Wawancara kembali dilakukan pada para staff penyidik, staff bagbinopsnal dan staff bagurkeu yang akan menjadi pengguna aktif (end user) dari sistem komputerisasi yang akan dirancang.

2. Requirement Structuring

Sub langkah kedua ini dilakukan berdasarkan sub langkah pertama, yaitu menstrukturisasi semua informasi yang telah diperoleh dari 
pelaksanaan sub langkah pertama tersebut.

3. Alternative Generating Design

Sub langkah ini dilakukan untuk menghasilkan sebuah rancangan sub baru dengan rancangan modul program aplikasi komputer.

\section{Rancangan Logika}

Semua fungsi dari sistem yang telah terpilih pada tahap analisa dijabarkan secara terpisah dari spesifikasi komputer tertentu.

\section{Rancangan Fisik}

Spesifikasi logika yang dihasilkan dari tahap rancangan logika diubah ke penggunaan teknologi tertentu secara terperinci, yaitu semua pemrograman dan konstruksi dari sistem yang sesuai.

\section{Implementasi}

Sistem informasi dikodekan, dites, diinstall dan didukung oleh organisasi. Dokumentasi, pelatihan dan bantuan diberikan pada pemakai. Di sini instansi akan mencoba memakai sistem yang telah dibuat atau diinstall. Selama percobaan akan diawasi oleh pembuat sistem atau programmer.

\section{Pemeliharaan}

Dengan terinstallnya sistem informasi secara sistematis diperlukan pemeliharaan dan peningkatan agar sistem tetap dapat beroperasi dan berguna sesuai kebutuhan pengguna seiring berjalannya waktu.

\section{HASIL DAN PEMBAHASAN} Use Case Diagram

Diagram ini digunakan untuk menggambarkan pengguna aplikasi dan kegiatan terhadap aplikasi. Pengguna diwakili oleh aktor sedangkan kegiatannya diwakili oleh Use Case.
Dalam sistem ini Diagram Use Case yang terbentuk adalah seperti gambar 4.5 Terdapat tiga actor yaitu bagbinopsnal, penyidik dan dirreskrimsus. Terlihat dari gambar bila staff binopsnal melakukan input data pengaduan, mencetak data pengaduan, input data kesatuan organisasi, validasi data kesatuan organisasi dan melakukan validasi surat-surat untuk kelengkapan administrasi penyidikan. Selanjutnya staff bin opsnal akan mencetak segala laporan yang berhubungan dengan organisasi dan administrasi. Kemudian staff penyidik akan mengecek pesan, mencetak surat dan laporan. Selanjutnya Dirreskrimsus akan menginputkan disposisi dan mengevaluasi laporan

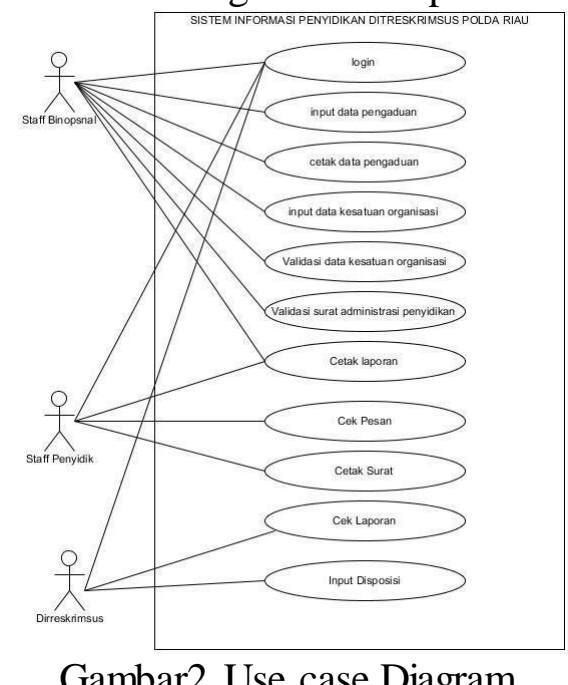

Gambar2 Use case Diagram

\section{Activity Diagram Baru}

Pada gambar dibawah ini menunjukkan aliran kerja dari system yang dirancang, terdapat start state yang menunjukkan awal dari aktivitas system baru yaitu dimulai dari login, dengan memasukkan user name dan password, jika user name dan password yang diinputkan dengan benar maka user dapat masuk ke dalam system dan melakukan pengolahan data. 


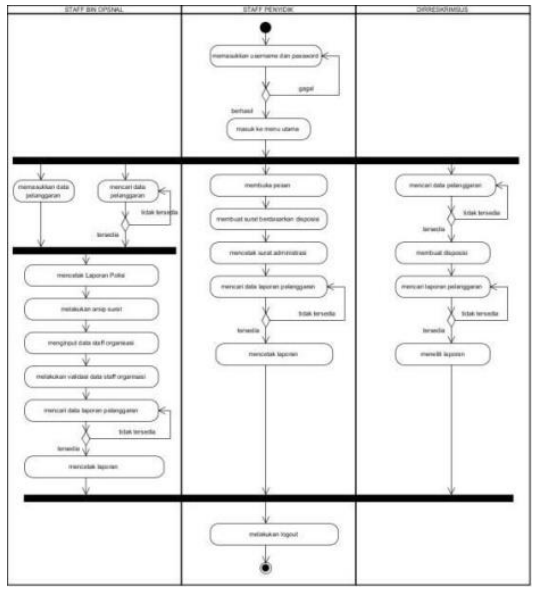

Gambar3 ActivityDiagramBaru

\section{Class Diagram}

Pada gambar class diagram dibawah terdapat beberapa Class, Class tersebut terdiri dari: korban, terlapor, saksi, surat, bap, pelapor, pelanggaran barang bukti, tindakan, organisasi, dan subditunit. Setiap Class memiliki atribut yang digunakan untuk mengidentifikasi jenisnya dan isi dari system yang telah dirancang.

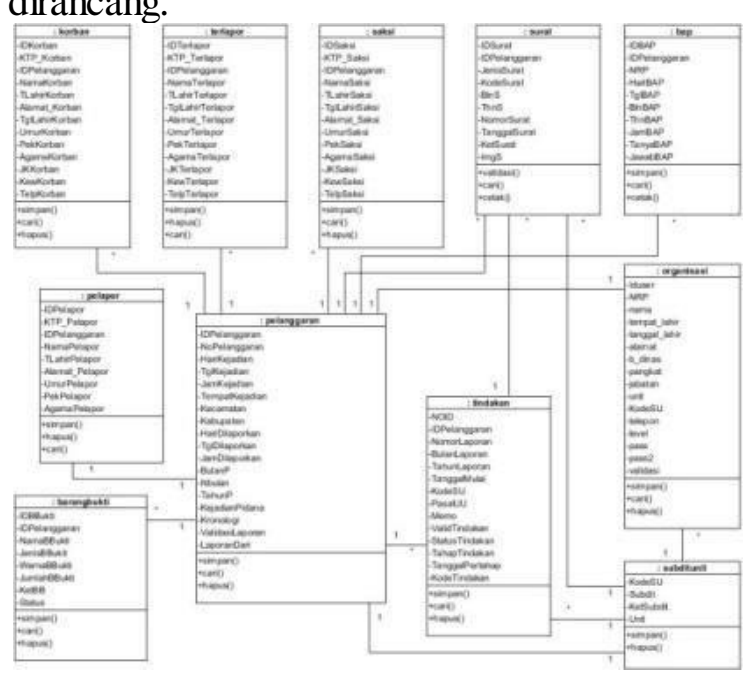

Gambar4 ClassDiagramBaru

\section{State Diagram Baru}

State Diagram menggambarkan realtime pada saat proses login dilaksanakan. Dimana setiap user akan login, akan dilakukan verifikasi user name dan password terlebih dahulu. Jika user dikenali, maka proses login sukses dilakukan, jika user tidak dikenali maka proses login akan dibatalkan.

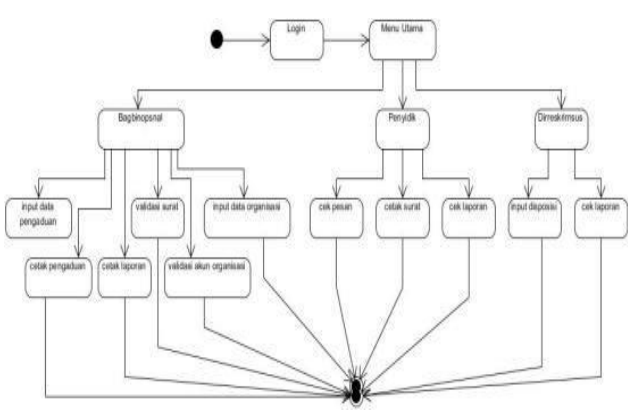

Gambar 5 State Diagram Baru

\section{Sistem Informasi Penyidikan}

- Form Login

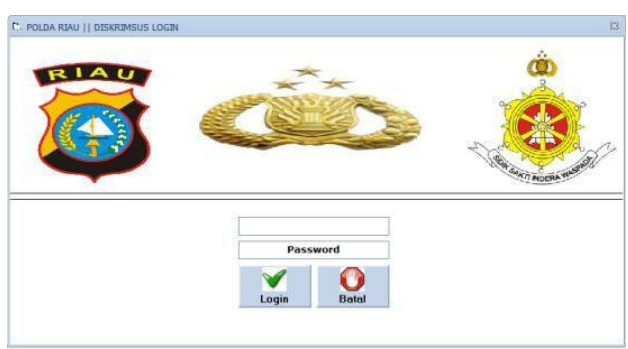

Gambar 6 Form Login

- Form Menu Utama

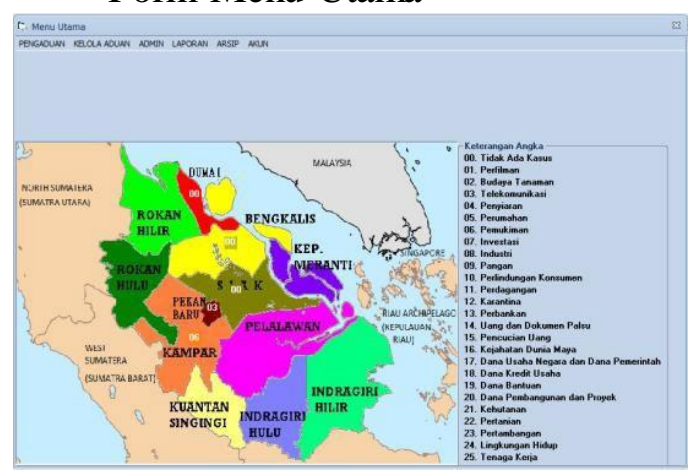

Gambar 7 Form Menu Utama

- Form Pengaduan

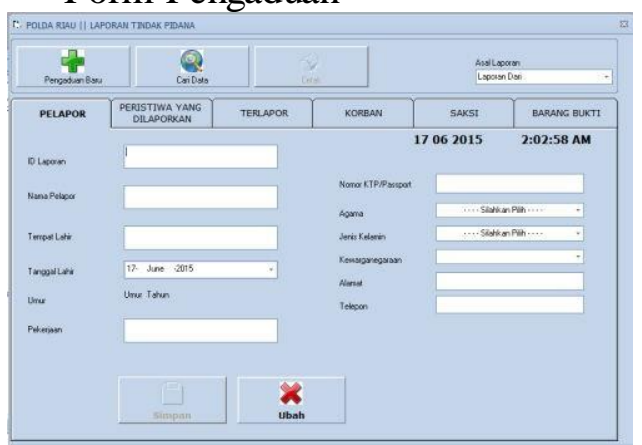

Gambar 8 Form Pengaduan 
Form Data Peristiwa

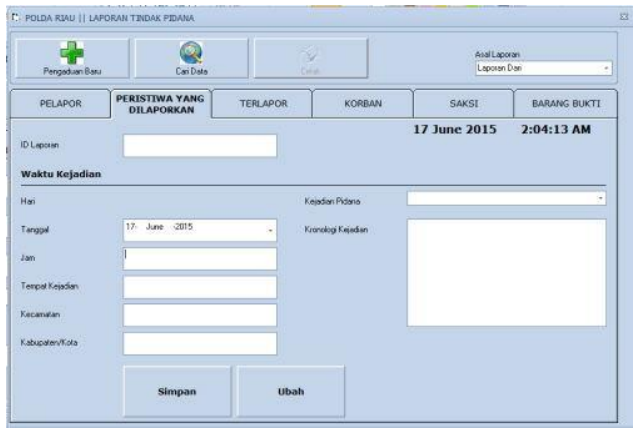

Gambar 9 Form Data Peristiwa

- Form Data Terlapor

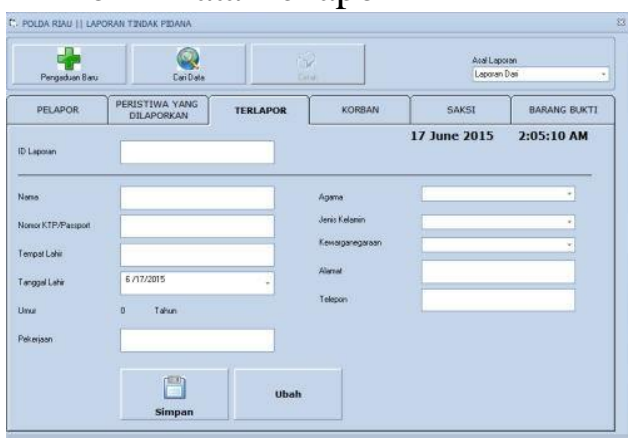

Gambar10 Form Data Terlapor

- Form Data Korban

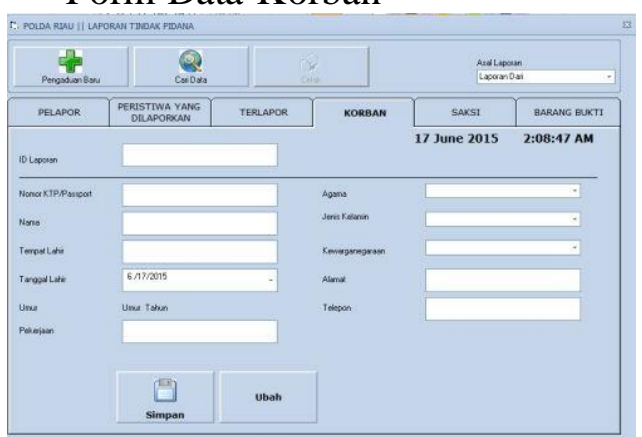

Gambar 11 Form Data Korban

- Form Data Saksi

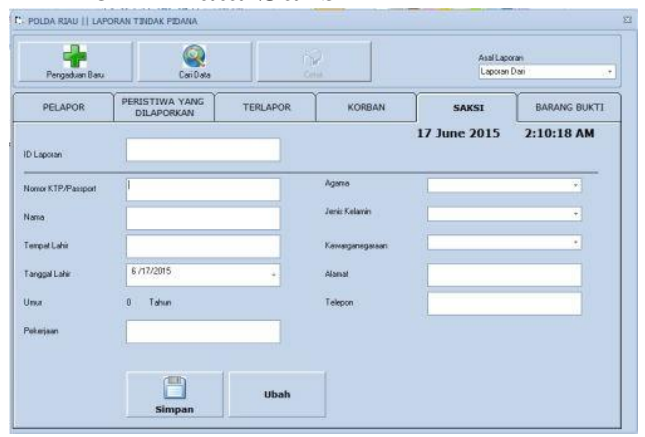

Gambar12 Form Data Saksi
- FormDataBarangBukti

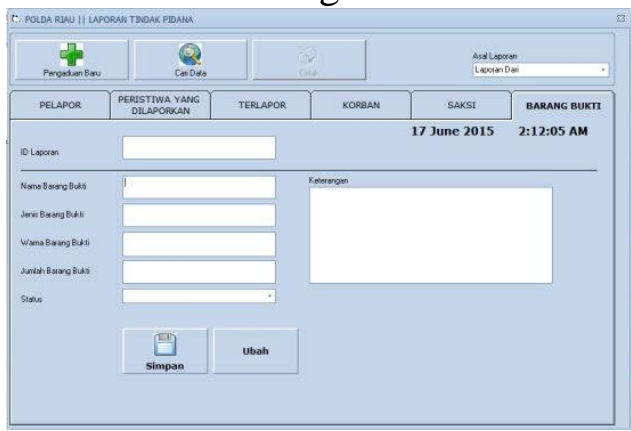

- FormKèlōaAdūan

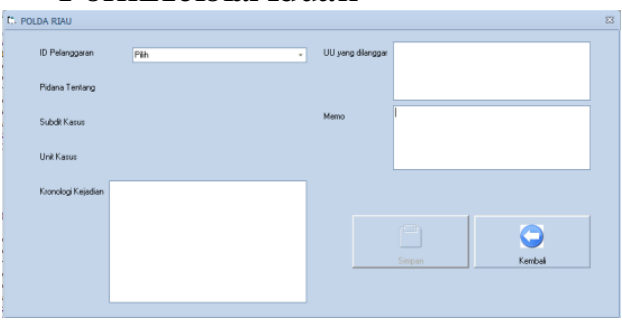

Gambar14 Form Kelola Aduan

- Form Arsip Surat

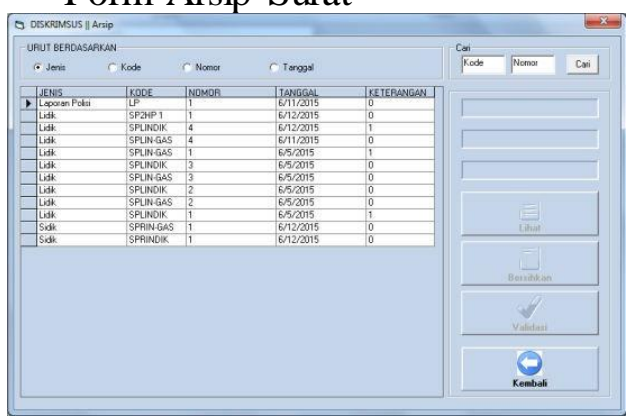

Gambar 15 Form Arsip Surat

- Form Cetak Laporan

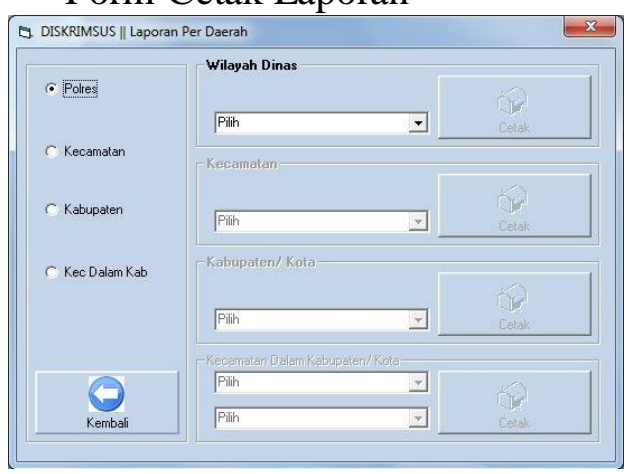

Gambar 16 Form Cetak Laporan 


\section{SIMPULAN}

Berdasarkan penelitian yang telah dilakukan, maka diperoleh kesimpulan sebagai berikut :

1. Penggunaan sistem informasi penyidikan berbasis client server yang diusulkan ini dapat membantu Kantor Ditreskrimsus Polda Riau dalam memberikan pelayanan dan penanganan secara cepat dan maksimal.

2. Penggunaan sistem penyidikan berbasis client server ini dapat mempercepat proses distribusi disposisi laporan secara tepat sasaran kepada pihak-pihak yang berkepentingan karena sistem dapat diakses oleh masing-masing unit.

3. Penggunaan sistem informasi penyidikan ini mampu membagi wilayah di provinsi Riau berdasarkan jenis kejahatan khusus yang ada sehingga dapat membantu pimpinan dalam mengambil keputusan untuk meningkatkan keamanan di provinsi Riau.

4. Penggunaan jaringan pada kantor Ditreskrimsus Polda Riau ini akan membantu mempercepat penyidikan yang berguna untuk kepentingan peradilan, operasional dan pengawasan penyidikan.

DAFTAR RUJUKAN

Al Fatta, Hanif. 2009. Analisis dan Perancangan Sistem Informasi untuk keunggulan bersaing perusahaan dan organisasi modern. Yogyakarta : Andi Offset

Hendarso Danuri, Bambang. 2010. Peraturan Kepala Kepolisian Negara Republik Indonesia No 22 tentang Susunan Organisasi dan Tata Kerja pada tingkat Kepolisian Daerah.
Hendarso Danuri, Bambang. 2010. Peraturan Kepala Kepolisian Negara Republik Indonesia No 23 tentang Susunan Organisasi dan Tata Kerja pada tingkat Kepolisian Resort dan Sektor.

Jogianto, HM. 2009. Analisis dan Desain. Yogyakarta : Andi Offset

Keraf, Prof. Dr. Gorys. 2001. Komposisi. Ende : Nusa Indah

Kitab Undang-Undang Hukum Acara Pidana (KUHAP) No. 8 Tahun 1981

Kurniawan, Wiharsono. 2007. Computer Starter Guide Jaringan Komputer. Yogyakarta : Andi Offset

Kusrini dan Andri Koniyo. 2007. Tuntunan Praktis Membangun Sistem Informasi Akuntansi dengan Visual Basic \& Microsoft SQL Server. Yogyakarta: Andi Offset

Ladjamudin, Al Bahra bin. 2013. Analisis Desain Sistem Informasi. Yogyakarta : Graha Ilmu

Mulyanta, Edi S. 2005. Pengenalan protokol jaringan wireless. Yogyakarta : Andi Offset

Ningsih, Nurhayati., 2010, Sistem Informasi E-Paspor, Pelayanan Publik, Keimigrasian di Kota Bandung. Skripsi UNIKOM.

Nugroho, Adi.2005. Analisis dan Perancangan Sistem Informasi Dengan. Metodologi Berorientasi Objek. Bandung : Informatik a

Pradopo, Timur. 2012. Peraturan Kepala Kepolisian Negara Republik Indonesia No 2 tentang Tata cara penanganan pengaduan masyarakat di lingkungan Kepolisian Neraga Republik Indonesia. 
Pratama, I Putu Agus. 2014. Sistem Informasi dan Implementasinya. Bandung : Informatika

Sudargo, Paulus. 2004. Pemrograman Berorientasi Objek Menggunakan Delphi. Yogyakarta : Andi Offset

Sutanta, Edhy. 2011. Basis Data dalam Tinjauan Konseptual. Yogyakarta : Andi Offset

UU No. 14 Tahun 2008 tentang Keterbukaan Informasi Publik

Wijaya, Suryana. 2013. Sistem Informasi Akademik Universitas Islam Negeri (UIN) Sunan Kalijaga Yogyakarta Berbasis Android

Yuliani, 2014, Perancangan Sistem Pendaftaran Penerimaan Calon Mahasiswa Baru Online Kampus Pelita Indonesia Pekanbaru Berbasis Web. Pekanbaru : Skripsi STIKOM PELITA INDONESIA.

Zainal Abidin, 2012. Sistem Pengolahan Data Terpadu Pada PT. Berjaya Tours dan Travel Berbasis Client Server. Pekanbaru : Skripsi STIKOM PELITA INDONESIA

http://id.wikipedia.org/wiki/MySQL http://id.wikipedia.org/wiki/Open_Datab ase_Connectivity

http://id.wikipedia.org/wiki/Pemrograma n_berorientasi_objek

http://id.wikipedia.org/wiki/Visual_Basic http://php-mysql-solution.blogspot.com http://www.apachefriends.org/en/xampp. html. 